\title{
Suspicious minds: Police Attitudes to Mental Ill Health
}

\author{
Sean Bell ${ }^{1}$ and Sue Palmer-Conn ${ }^{2}$ \\ ${ }^{1}$ Liverpool Centre for Advanced Policing Studies (LCAPS), Liverpool John Moores University, Merseyside, UK. \\ ${ }^{2}$ Faculty of Science, Natural Sciences and Psychology, Liverpool John Moores University, Merseyside, UK. \\ Correspondence: Sean Bell, E-mail: S.Bell2@2010.1jmu.ac.uk
}

Received: November 13, 2018

Accepted: December 3, 2018

Online Published: December 13, 2018

doi:10.11114/ijlpa.v1i2.3878

URL: https://doi.org/10.11114/ijlpa.v1i2.3878

\begin{abstract}
Policing and mental ill health are inextricably entwined. The police have a role to respond to distressed persons and depending on the circumstances act as mental health practitioners or law enforcement officers. Policing can have an impact on the mental health of those delivering the service. Those working within policing will either experience, work alongside and/or manage colleagues with mental ill health. Therefore it is important that the attitudes of police officers and police staff to mental ill health are established. The research employs the Time to Change Survey to bench mark police attitudes against the general public. Results indicate that police officers/staff hold similar attitudes to the public. However police officers are less supportive of community based interventions. Police data portrays an organisation where mental health related stigma persists, where discussing or seeking help is avoided and having a mental health issue seen as career destroying.
\end{abstract}

Keywords: police, attitudes, mental ill health, culture, stigma, discrimination

\section{Introduction}

Good mental health is the foundation for thinking, communication, learning, resilience and self-esteem. Mental health is also key to relationships, personal and emotional well-being and contributing to community or society (American Psychiatric Association, 2017). Poor mental health is associated with stressful work conditions, discrimination, stigmatisation, social exclusion, exposure to danger and poor physical health (Mental Health Foundation, 2016). Therefore it is understandable that people may not want to talk about poor mental health.

Mental illness can affect anyone. Depending on the definition of mental illness, between ten and twenty five percent of people living in the United Kingdom will experience mental illness at some point in their lives. (NHS, 2017). Research by MIND has revealed emergency workers in the UK are more likely than civilian counterparts to experience a mental health issue, but less likely to seek help (MIND, 2015).

Due to policing demographics, there is an overlap between groups known to be at increased risk of developing mental health problems and police officers (Samaritans, 2013). Police personnel top the scale with $90 \%$ of police personnel having experienced stress or poor mental health at work. Furthermore $61 \%$ have had personal experience of mental health problems - the highest of all blue light services (The Police Federation of England and Wales, 2016).

The World Health Organisation defines stigma as 'a mark of shame, disgrace or disapproval which results in an individual being rejected, discriminated against, and excluded from participating in a number of different areas of society' (WHO, 2001, p16). Due to mental health-related stigmatization, 'many people who would benefit from mental health services opt not to pursue them or fail to fully participate once they have begun' (Corrigan, 2004, p. 614). Similarly due to cultural issues police officers do not wish to be seen as weak by colleagues or to hamper their career prospects by seeking mental health support (Karaffa \& Tochkov, 2013).

According to Cotton (2004) police officers attitudinal attributes can influence their behaviour when dealing with people with mental health issues and advocated measuring such attitudes. More recently, Glendinning \& O'Keefe (2015) highlighted a similar need to assess the attitudes of the police towards mental ill health as their attitudes can have a significant impact on the community. Yet studies of police attitudes to mental ill health are rare (Bell \& Eski, 2016; Glendinning \& O'Keefe, 2015; Hansson \& Markstrom, 2014).

Police officers alongside the communities they live and work in share similar stereotypical views about mental health (Pinfold, et al., 2003; Cotton, 2004). However, the former have a duty to be more knowledgeable and understanding of 
the issues surrounding mental health (Bradley, 2009), and would expect to find more positive attitudes. As stated above there has been limited research into the attitudes of police officers and even less so police staff attitudes to mental health. The aim of this study was to describe and compare police officers and staff attitudes towards people with mental ill health and the issues and influences associated with such attitudes.

The above indicates the need for a study such as this, to address the gaps in the literature. By using established scales and subscales, Attitudes to Mental Illness questionnaire (NHS, 2016) and statements developed by the author (see Table 4) the study aims to firstly measure police officers (warranted officers) and police staff (unwarranted employees who perform a variety of administrative and operational support functions, many performing duties previously delivered by warranted police officers) attitudes to mental illness and compare them to each other and those of the wider community and secondly by introducing a qualitative element to the survey by inviting participants to make comment alongside the questionnaire to capture the thoughts and opinions they associate with mental ill health (Kanika, et al., 2017). Employing such a mixed methods approach can provide context and a deeper understanding of survey responses than quantitative data alone (Creswell \& Plano Clark, 2007).

\section{Literature}

Despite the prevalence of mental ill health and many public education campaigns such as Time to Change and MIND, stigma and discrimination continues to impact negatively on the lives of people with mental health issues. In fact 'Stigma and discrimination in relation to mental illnesses have been described as having worse consequences than the conditions themselves' (Thornicroft, et al., 2016). According to Time to Change, 87\% of respondents in 2014 agreed that people with mental illness experience stigma and discrimination (Time to Change, 2015). Unfortunately, the workplace is the second most common area (after family and friends) where mental health stigma is encountered (Wahl, 1999).

Corrigan (2004) identifies stigma on the public level and the self, arguing that they are inextricably linked and share the same characteristics of prejudice, discrimination and negative stereotyping. 'This perspective represents self-stigma as a hierarchical relationship; a person with mental illness must first be aware of corresponding stereotypes before agreeing with them and applying self-stigma to one's self' (Corrigan, et al., 2009, p.75). Therefore, it is possible that officers/staff are more critical of themselves than their peers when it comes to mental health issues. In fact Soomro \& Yanos (2018, p.7) 'found that officers meeting criteria for current PTSD endorsed more stigma about mental illness and more negative attitudes about seeking mental health treatment' than the general population'. Which suggests officers with mental illness maybe stigmatising their colleagues in a similar position. Karaffa and Tochkov (2013) suggest that police officers, like the general public, experience the same social-cognitive effects of stigma which in policing are compounded by their perceived relationships with colleagues. Officers who cannot control their emotions can be viewed as unreliable when responding to critical incidents. As a result, officers will invariably suppress their emotions (Bonifaco, 1991).Furthermore officers seeking counselling or support can be viewed as weak and lacking resilience by their peers further heightening feelings of stigmatisation (Toch, 2002). Therefore, fear about fitness to practice may prevent officers/staff seeking help and support (Ombudsman Ontario, 2012, UNISON, 2014) potentially leading to an intensification of the mental health issue.

Recent research suggests, stigma is still prevalent in policing (Bullock \& Garland, 2017; Turner \& Jenkins, 2018). 'The Ontario Ombudsman's noted that many officers felt betrayed by their supervisors and alienated from their peers when their operational stress injuries became known' (Stuart, 2017, p. 18). Challenges remain in addressing the problem, 'it was also clear that changing stigmatizing attitudes has been difficult and attempts have often fallen short of what was anticipated.' (Bullock \& Garland, 2017, p.12). Within the UK several forces and the Blue Light Campaign have attempted to open the debate about mental health in policing. It is questionable how many force initiatives have attempted to measure staff attitudes to mental illness at any stage in the process or indeed set a bench mark.

According to Houdmont (2017) police officer prevalence of minor psychiatric morbidity has reported between 42 per cent and 58 percent compared to the general UK working population of 19.5 per cent. The Police Federation of England and Wales, Police Officer Welfare, Demand, and Capacity Survey found that 39 per cent of police officers reported their job to be very or extremely stressful compared to 16 per cent of the general working population based on Health and Safety Executive data (Houdmont \& Elliot-Davies, 2016). Likewise police staff appear to suffer similar stress. The UNISON, Police Staff Stress Survey Report found that $32 \%$ of police staff are 'very stressed' and $62 \%$ are 'moderately stressed' (UNISON, 2014).

These statistics can be associated with officers and staff seeking help for mental illnesses related to their role. UNISON report that $15 \%$ of police staff have been referred to their force occupational health department due to stress and PFEW that 39\% of Police Officers had sought help for feelings of stress, low mood, anxiety, or any other difficulties with mental health and wellbeing. Similarly MIND (2015) reported that police personnel reported a higher mental health 
service usage (31\%) than the general population (24\%).

Police work related mental illness maybe be organisational linked to poor management, shifts (Brown \& Campbell, 1994), poor communication and lack of support from senior ranks and increased workload (Crowe \& Stradling, 1993) or operational stressors in the form of traumatic incidents (Abdollahi, 2002). The latter appear to have less impact than the former (HSE, 2007; UNISON, 2014; MIND, 2015; Houdmont \& Elliot-Davies, 2016). However, that is not to underestimate the impact of traumatic events on those who deliver policing. The most commonly classified police operational stressors identified by Abdollahi (2002) are dealings with the judicial system, public scrutiny and media coverage, officer involved shootings, encountering victims of crime and fatalities, community relations and encountering violent/unpredictable situations' (Abdollahi, 2002). Police staff are not immune from such stressors, they deliver a range of quasi policing roles with some operational crossover and or limited police powers exposing them to similar traumatic incidents as police officer colleagues (McCarty \& Skogan, 2012; Regehr, et al., 2013; Alderden \& Skogan, 2014).

The impact of these stressors on policing and thus the service to the public is striking. The figures are stark. In 2015 the British Broadcasting Company (BBC) conducted a Freedom of Information request to 46 UK police Forces. From the 40 responses it was evident that police officers and staff are experiencing high levels of absence due to mental ill health. The data indicated that during the five year period from 2010 to 2015 there has been a $35 \%$ increase in police officers and staff taking long term (in excess of 28 days) sick leave due to mental ill health. According to the figures there were 4,544 cases of psychological related absences in 2010 resulting in 19,825 days absence rising to 6,219 cases in 2015 resulting in 22,547 days absence an increase of $12 \%$. This is against a backdrop of falling police officer and police staff numbers of 17,000 and 20,000 respectively (BBC, 2016).

\section{Problem Definition}

- As stated above there is scant research regarding police officer/staff attitudes to people with mental ill health issues and even less of their attitudes to colleagues with mental health issues. Understanding such attitudes are important as they have an influence on police officer values, behaviours and subsequent actions when dealing with the public or colleagues (Bailey, et al., 2001; Stuart, 2017). Therefore, the following research objectives were formulated. A critical exploration of police officer and staff attitudes to mental illness and its impact in the workplace.

- A comparative analysis of police officer and staff attitudes with members of the general public.

- A critical analysis of the factors that underpin these attitudes.

\section{Method}

\subsection{Design}

The current study aims to replicate within policing a survey carried out annually by Time to Change which examines the changing public attitudes to mental health. A bank of statements and raw data for the 2015 public survey was provided by TNS BMRB to the researcher for direct comparison with the police data. The survey consists of several self-report inventories outlined below under materials. Unlike the public survey, the police survey included open ended questions inviting participants to comment if they wished to do so. The responses provide the qualitative data and analysis below.

The Time to Change public survey employs random location sampling techniques to ensure respondents reflect the national profile for geography and social-economic status. Time to Change interviews were carried out by trained staff in respondents' homes using Computer-Assisted Personal Interviewing (CAPI). Such an option was not open to the researcher. Instead the police survey was distributed via email by Police Federation of England and Wales (PFEW) to a random sample of 2000 serving police officers. UNISON did likewise to individual Branch Boards for onward transmission to police staff members. As it was at the discretion of each branch board this only occurred in 19 Forces.

The difference in data collection can impact on results. However, Burkhill et al. (2016) when comparing differences in data collection methods found over $90 \%$ of responses did not change across modes, and the vast majority of respondents gave inconsistent answers to no more than a handful of questions. Research suggests online surveys are deemed to be effective methods of data gathering and respondents may find it easier to answer sensitive issues and are more likely to answer open questions in depth in an online questionnaire (Burkhill, et al., 2016, Tourangeau, et al., 2003). Furthermore a similar approach was undertaken by Brooker \& Sirdifield (2009) to benchmark attitudes of probation staff to mental ill health against the general public and Glendenning \& O'Keefe (2015) likewise with police officers and the public.

The research is one of the largest of its kind benefiting from a nationwide survey with police officer responses from three quarters of all police forces in England and Wales. However, the responses from individual Forces varied from single figures into several hundred. A more equally distributed response would allow for Force comparisons and 
regional comparisons. Additionally further analysis is required to ascertain demographic impacts on attitudes to mental health.

The police study received approval from Liverpool John Moores University Research and Ethics Committee (Ref: 15/HSS/002 -9/2/15).

\subsection{Participants}

Police officer responses were collected from 33 out of the 43 Home Office forces plus British Transport Police. Police staff responses were collected from 19 forces. The disparity in forces between officer and staff returns is due to the regional branch distribution method employed by Unison members as opposed to national distribution by PFEW to officer members.

Table 1. Demographics

\begin{tabular}{|c|c|c|c|}
\hline & Time to Change Public & Police officers & Police staff \\
\hline Numbers & 1747 & 764 & 291 \\
\hline Males & $849(49 \%)$ & $473(62 \%)$ & $113(39 \%)$ \\
\hline Females & $898(51 \%)$ & $279(37 \%)$ & $176(61 \%)$ \\
\hline Trans \& Not Stated & & 10 & 0 \\
\hline \multirow[t]{3}{*}{ Age range } & $16-34$ years $33 \%$ & $18-34$ years $22 \%$ & $16-34$ years $25 \%$ \\
\hline & $35-54$ years $33 \%$ & $35-45$ years $76 \%$ & $35-54$ years $59 \%$ \\
\hline & $55+$ years $34 \%$ & $55+$ years $2 \%$ & $55+$ years $17 \%$ \\
\hline \multirow[t]{5}{*}{ Length of service } & & $0-2$ years $3 \%$ & $0-2$ years $7 \%$ \\
\hline & & $3-10$ years $22 \%$ & $3-10$ years $35 \%$ \\
\hline & & $11-20$ years $43 \%$ & $11-20$ years $34 \%$ \\
\hline & & $21-30$ years $30 \%$ & $21-30$ years $14 \%$ \\
\hline & & $30+$ years $2 \%$ & $30+$ years $10 \%$ \\
\hline \multirow[t]{4}{*}{ Ranks/grades } & & Constables $72 \%$ & Operational $45 \%$ \\
\hline & & Sergeants $18 \%$ & Administrative $43 \%$ \\
\hline & & Inspector $8 \%$ & Management $12 \%$ \\
\hline & & Superintendent $2 \%$ & \\
\hline
\end{tabular}

\subsection{Materials}

The research employed the Attitudes to Mental Illness questionnaire (TNS BMRB, 2015) which consisted of:

a. Community Attitudes to Mental Health Index (CAMI) (Taylor \& Dear, 1981). Variations of this questionnaire have been used effectively in several countries to test public attitudes to mental health and that of health care professionals (Chambers et. al., 2010; Morrison, 2011; Friedrich, 2013) and with police officers (Clayfield et. al., 2011; Glendinning \& O'Keefe, 2015). The overriding Attitudes to Mental Health Illness questionnaire (TNS BMRB, 2015) consists of four subscales Fear and Exclusion, Understanding and Tolerance, Integrating People into the Community and Causes and Needs of People with Mental Illness measured on a five point Likert scale, with the intention of identifying people who accept or reject people with mental illness within their community. The questions cover a wide range of issues, from attitudes towards people with mental illness, to opinions on service provision for people with mental health problems. The total score is calculated so that higher CAMI scores indicate less stigmatising attitudes. Its overall internal consistency in the data measured using Cronbach's $\alpha$ is 0.87 .

b. Mental Health Knowledge Schedule (MAKS) (Evans-Lacko, et al., 2010). The MAKS comprises six items covering stigma-related mental health knowledge areas: help seeking, recognition, support, employment, treatment, and recovery, and six items that inquire about classification of various conditions as mental illnesses. The overall internal consistency among items is 0.65 (Cronbach's $\alpha$ ). The total score is calculated so that higher MAKS scores indicate greater knowledge.

c. Reported and Intended Behaviour Scale (RIBS) (Evans-Lacko, et al., 2011) The Time to Change survey employs four domains comprised: living with, working with, living nearby and continuing a relationship with someone with a mental health problem. However to reduce the overall size of the survey this research only employed the working with statement. Therefore Cronbach's $\alpha$ not required. 


\section{d. Police specific questions}

In order to better understand police culture, the author included additional questions relating to policing including, provision of training, disclosure of mental illness, relationship with colleagues, and potential impact of disclosure on career prospects. The overall internal consistency among items is 0.791 (Cronbach's $\alpha$ ). The total score is calculated so that higher scores indicate more positive outcomes.

\section{Findings and Discussion}

Statistical analysis was carried out using SPSS 22. Significance of differences was tested using the two-tailed t-test for independent samples (comparing two variables) and multivariate analysis of variance with a Tukey test of significance being conducted post hoc (comparing three or more variables). The whole percentages shown in the data are rounded, but the significance tests have been carried out on the true percentages. Statistical significance levels were set at 0.05 that is $95 \%$ confident that differences reported are real rather than occurring just by chance.

\subsection{CAMI and MAKS}

Table 2. CAMI and MAKS Scale

*Signifies where ANOVA post hoc difference arose and results are significantly different.

\begin{tabular}{|c|c|c|c|c|c|}
\hline Mean Scores & Public & Police officers & Police staff & Significance, $\mathrm{p}$ & F Value \\
\hline Fear and exclusion & 32.57 & 32.74 & 34.14 & 0.001 & 11.95 \\
\hline \multicolumn{6}{|c|}{ Post-hoc Test: public vs officers: $\mathrm{p}=0.462$, public vs staff: $\mathrm{p}=0.001^{*}$, officers vs staff: $\mathrm{p}=0.001^{*}$} \\
\hline $\begin{array}{l}\text { Understanding and } \\
\text { tolerance }\end{array}$ & 31.28 & 31.35 & 32.12 & 0.001 & 8.49 \\
\hline \multicolumn{6}{|c|}{ Post-hoc Test: public vs officers: $\mathrm{p}=0.396$, public vs staff: $\mathrm{p}=0.001^{*}$, officers vs staff: $0.009^{*}$} \\
\hline $\begin{array}{l}\text { Integration into the } \\
\text { community }\end{array}$ & 34.28 & 32.11 & 34.04 & 0.001 & 44.71 \\
\hline \multicolumn{6}{|c|}{ Post-hoc Test: public vs officers: $\mathrm{p}=0.001^{*}$, public vs staff: 0.995 , officers vs staff; $0.001^{*}$} \\
\hline Causes and needs & 11.52 & 12.99 & 13.05 & 0.001 & 113.97 \\
\hline \multicolumn{6}{|c|}{ Post-hoc Test: public vs officers: $p=0.001 *$, public vs staff: $p=0.001 *$, officers vs staff: $p=0.804$} \\
\hline Total CAMI & 109.64 & 109.51 & 113.83 & 0.001 & 12.878 \\
\hline \multicolumn{6}{|c|}{ Post-hoc Test: public vs officers: $\mathrm{p}=0.973$, public vs staff: $\mathrm{p}=0.001^{*}$, officers vs staff: $\mathrm{p}=0.001^{*}$} \\
\hline Total MAKS & 45.76 & 47.08 & 48.04 & 0.001 & 40.382 \\
\hline
\end{tabular}

The results above indicate that police officers and staff like members of the public generally hold positive attitudes about mental ill health. Members of police staff were more positive than their police officer colleagues and the general public. As far as police officers are concerned the results support findings from other studies (Cotton, 2004; Clayfield, et al., 2011) in contrast to Soomro \& Yanos (2018) who found police officers were more likely to endorse negative streotypes. Using the CAMI scale (Table 3) as a bench mark police staff have the significantly highest total score compared to the general public and in turn police officers who share similar results. This would suggest that police staff have better attitudes to people with mental ill health than the public or police officers. However, further analysis reveals that in three of the four scales (Fear and Exclusion, Understanding and Tolerance and Causes and Needs) the public score lower than police officers and police staff. The exception being Integration into the Community where police officers score significantly lower than the public and police staff.

Therefore, the total CAMI score could be construed as deceptive, as in three of the four subscales the police family score higher than the general public the exception being Integrating People with Mental Health Issues into the community. This relates to other research, as CAMI scales encompass broad concepts and statements and are open to interpretation therefore they are not mutually exclusive and people may hold conflicting attitudes between fear and exclusion, understanding and tolerance, integration and causes of mental ill health at the same time (Wolff, et al., 1996).

Analysis of the Integration into the Community sub scale reveals that public respondents and police officers and police staff differed significantly. The results suggests that the public and police staff are significantly more likely to support integration into the community of people with mental ill health than police officers. Within the subscale (Appendix A) police officers were significantly less likely to be supportive of the statements, Q41'People with mental illness are far less of a danger than most people suppose', Q26 'Less emphasis should be placed on protecting the public from people 
with mental illness' and Q43 'The best therapy for many people with mental illness is to be part of a normal community'. These statements resulted in the public being significantly more supportive than police staff and police officers with police officers being the least supportive.

This theme continues when exploring the statements, Q45 'Residents have nothing to fear from people coming into their neighbourhood to obtain mental health services' and Q27 'Mental hospitals are an outdated means of treating people with mental illnesses' which maintains the same pattern of public, police staff, police officer decreasing support.

The results indicate that police staff are less supportive of integration and police officers even less so than the general populace.

In contrast within the same subscale the police group scored significantly higher in response to Q48 'People with mental health problems should have the same rights to a job as anyone else', Q42 'Most women who were once patients in a mental hospital can be trusted as babysitters' and Q25 'Mental illness is an illness like any other'. It can therefore, be argued that the makeup of the responses reflect policing experience or perceptions of the dangerousness of some people with mental ill health and that the public require protection (Watson, et al., 2004; Cummins, 2012). Furthermore, there is a recurring frustration in having to deal with increased mental health related incidents caused by a perceived lack of activity from social services and mental health agencies. Combined with the impact of austerity measures this can have a negative impact on some police attitudes (Cummins, 2012; Morgan \& Paterson, 2017). A male police constable summed this up,

Disagree strongly - we need to spend more on MH services (a) to help more people - preventing them reaching crisis by making MH services more easily accessible and timely, and by responding to crisis (b) to reduce demand on police (c) to reduce demand on ambulance (d) to reduce demand on $A \& E$

Even then the genuineness or credibility of those seeking help is questioned (Watson, et al., 2004). A female police sergeant challenged the legitimacy and authenticity of some of the people police may encounter

'Because it goes on those patients who do not actually need it. To much effort is spent on people who are drunk, who are claiming mental health to get attention from loved ones .....'

Again this does not paint the whole picture, police officers/staff appear to be supportive of individuals with mental health issues, seeing mental ill health on a par with physical illness, supporting rights to employment and would be trusting of recuperative mental health patients looking after children.

Further examination of the CAMI statements within Fear and Exclusion (Appendix A) responses highlights a similar theme of social exclusion. Police officers and police staff are less likely to disagree with the statements Q47 'Locating mental health facilities in a residential area downgrades the neighbourhood' and Q38 'I would not want to live next door to someone who has been mentally ill' than the public or police staff colleagues. Despite this police officers and staff scored higher on the Fear and Exclusion subscale. Trovato (2000), in Cotton (2004, p. 143) sheds some light on the apparent contradictory findings " On the one hand, officers feel a profound obligation toward emotionally disturbed persons as strongly indicated in the 'Benevolence' scores; while, on the other hand, they feel the public needs protection from them."

Employing the MAKS Schedule (Appendix A) the police family were statistically more knowledgeable about mental ill health than the public. Research suggests that people with better mental health-related knowledge display less personal stigma and less fear and discomfort when interacting with people with mental ill health ( (Evans-Lacko, et al., 2010) .

Comments submitted by participants were generally supportive of most statements. However, there was an underlying and consistent theme which drew attention to the 'deserving ill' and the supposed 'self-inflicted ill' who shun mental health services and engage in substance misuse. This is identified in many cases as a trait and not an illness. A male police staff member suggested that such ill health was as the result of life style choices, 'Drug induced i.e. cannabis related mental health issues, I have no sympathy for, as they had a choice'. Whilst a female police staff member disapproved of those who disengage with support services, 'I have no sympathy for people who don't engage with the services once they have been offered and make no attempts to help'.

Previous research suggest police officers make judgements about the causes and effects of mental ill health and to what degree personal responsibility and behaviour has on their wellbeing. (Watson, et al., 2004; Godfedson, et al., 2011). Watson, et al., (ibid) goes further suggesting that if people perceive that the cause of a situation is controllable, they will judge the individual to be responsible themselves. 


\subsection{Consulting and Talking about Mental Health}

Table 3

*Signifies where ANOVA post hoc difference arose and results are significantly different. (Likert Scale 1 to 6 )

\begin{tabular}{|c|c|c|c|c|c|}
\hline Mean scores & Public & $\begin{array}{l}\text { Police } \\
\text { officers }\end{array}$ & Police staff & Significance, $\mathrm{p}$ & F Value \\
\hline $\begin{array}{l}\text { In the future I would be willing to work } \\
\text { with someone with a mental health } \\
\text { problem }\end{array}$ & 4.16 & $4.51^{*}$ & $4.65 *$ & 0.001 & 61.782 \\
\hline \multicolumn{6}{|c|}{ Post-hoc Test: public vs officers: $p=0.001^{*}$, public vs staff: $p=0.001^{*}$, officers vs staff: $p=0.101$} \\
\hline $\begin{array}{l}\text { If you felt you had a mental health } \\
\text { problem, how likely would you go to } \\
\text { your GP for help? }\end{array}$ & 4.13 & $3.93 *$ & 4.13 & 0.001 & 8.137 \\
\hline \multicolumn{6}{|c|}{ Post-hoc Test: public vs officers: $\mathrm{p}=0.001 *$, public vs staff: $\mathrm{p}=0.995$, officers vs staff: $0.033^{*}$} \\
\hline $\begin{array}{l}\text { If you felt you had a mental health } \\
\text { problem, how likely would you inform } \\
\text { friends and family }\end{array}$ & 5.07 & $4.08^{*}$ & $4.41 *$ & 0.001 & 82.026 \\
\hline \multicolumn{6}{|c|}{ Post-hoc Test: public vs officers: $\mathrm{p}=0.001^{*}$, public vs staff: $\mathrm{p}=0.001^{*}$, officers vs staff: $\mathrm{p}=0.979$} \\
\hline $\begin{array}{l}\text { If you felt you had a mental health } \\
\text { problem, how likely would inform your } \\
\text { current or prospective employer. }\end{array}$ & 3.65 & $2.46^{*}$ & $2.60 *$ & 0.001 & 127.17 \\
\hline
\end{tabular}

Participants in both surveys were asked about their likelihood of consulting a GP (Table 3) and speaking to prospective employers and friends and family if they were to experience mental ill health. Police officers and staff indicated they were reluctant to do any of these things as they were statistically less likely than members of the public to consult their GP (Q60), inform prospective employers (Q64), and talk to family or friends about a mental illness (Q62). Additionally police officers and staff were asked if they would seek help from their manager which the majority of respondents indicated they were unlikely to do so (Q61). This is in line with previous research as Westley, (1970) found police officers place a boundary between home and work, and are unlikely to burden or confide in family about the risks, dangers and impacts they encounter. Karaffa \& Tochkov, (2013) reported that officers are reluctant to access mental health support in fear of being seen as weak.

Continuing the work place theme a number of additional questions were posed. The first asking Q68 'In the future I would be willing to work with someone with a mental health problem'. Police officers/staff were statistically more willing to do so than the general public.

Table 3 indicates that police officers and staff are more supportive of others with mental health issues, and are more willing to work with people with mental health issues than the general public but paradoxically they are less likely to share their experiences with others. Police officers are the least likely to consult their GP or inform their current or future employer or confide in family and friends about mental ill health. 


\subsection{Police Specific Questions}

Table 4. Police specific questions

*Signifies where $\mathrm{T}$ test results are significantly different.

\begin{tabular}{|c|c|c|c|}
\hline Mean scores & $\begin{array}{r}\text { Polic } \\
\text { e officers }\end{array}$ & $\begin{array}{l}\text { Police } \\
\text { staff }\end{array}$ & $\begin{array}{l}\text { Significance, } \\
\mathrm{p}\end{array}$ \\
\hline $\begin{array}{l}\text { If I had a mental health problem I think my } \\
\text { managers would support me. }\end{array}$ & 3.31 & 3.65 & $0.01 *$ \\
\hline $\begin{array}{l}\text { If I had a mental health problem I think my } \\
\text { work colleagues would support me. }\end{array}$ & 3.56 & 3.76 & $0.017 *$ \\
\hline $\begin{array}{l}\text { If you felt you had a mental health problem, } \\
\text { how likely would you inform your colleagues }\end{array}$ & 3.05 & 3.42 & $0.001 *$ \\
\hline $\begin{array}{l}\text { Disclosing a mental health problem in the } \\
\text { police service is detrimental to future career } \\
\text { prospects. }\end{array}$ & 1.98 & 2.48 & $0.001 *$ \\
\hline $\begin{array}{l}\text { Police Officers/Staff with mental health } \\
\text { problems are treated as sympathetically as } \\
\text { officerslstaff with physical illness. }\end{array}$ & 2.39 & 2.79 & $0.001 *$ \\
\hline $\begin{array}{l}\text { Some people use stress as an excuse for being } \\
\text { absent from work. }\end{array}$ & 2.42 & 2.63 & $.026^{*}$ \\
\hline $\begin{array}{l}\text { My Force adequately prepares managers to } \\
\text { manage officers/staff who experience mental health } \\
\text { issues. }\end{array}$ & 2.13 & 2.56 & $0.001 *$ \\
\hline $\begin{array}{l}\text { My Force adequately prepares officers/staff to } \\
\text { deal with the stressful events they are likely to } \\
\text { encounter. }\end{array}$ & 2.07 & 2.63 & $0.001 *$ \\
\hline $\begin{array}{l}\text { Debriefing is used effectively to support } \\
\text { officers/staff who have experienced stressful events } \\
\text { within my Force. }\end{array}$ & 2.76 & 3.23 & $0.001 *$ \\
\hline $\begin{array}{l}\text { Within my Force there is sufficient support for } \\
\text { officers/staff experiencing mental health issues. }\end{array}$ & 2.58 & 3.06 & $0.001 *$ \\
\hline Total Score & $\begin{array}{l}26.2 \\
7\end{array}$ & 30.1 & $0.001 *$ \\
\hline
\end{tabular}

Police officers and staff were asked a series of questions (Table 4) about interactions with managers and colleagues if they had mental health issues. Police officers were less likely to agree that their managers or colleagues would support them than police staff. However, it should be noted that the figures are less than overwhelming in either case. Police officers and staff expressed the opinion that mental illness was not treated as sympathetically as physical illness, that police officers and staff were not adequately prepared to deal with the stressful events they may encounter. Consequently managers are not sufficiently equipped to manage officers who may have mental health issues. Debriefing is lacking or inadequate which, according to Turner \& Jenkins $(2018$, p.6) is 'a glaring omission that leaves police officers to internalise the impact of involvement in traumatic events' without suitable interventions.

As above it appears police officers and staff are suspicious of mental health related work absences with majorities supporting the statement (Q69) 'Some people use stress as an excuse for being absent from work'. Traditionally officers reporting stress or depression were seen by peers and supervisors to be 'swinging the lead' insinuating that reported absences are not genuine (Stuart, 2017; Turner \& Jenkins, 2018). Similarly to the scepticism displayed about mental ill health in CAMI and MAKS scales, the genuineness of colleague's mental illness is also called into question by respondents as displayed by a male sergeant, 'genuine illness - definitely, lead swingers - no.' 
Despite the overall aggregate scale scores the qualitative statements reveal an underlying cynicism towards mental health externally and in the relationship of officers and staff when dealing with colleagues or supervisors with a member of staff with mental ill health. It is for this reason the researchers have adopted the phrase 'suspicious minds'.

In general police officers were less likely than police staff to portray a positive appraisal or agree that they were sufficiently prepared or supported by the organisation for dealing with the stresses of police work and the impact on their mental health. Police officers returned a lower score to all the statements than their police staff colleagues. It is of note that police officers and police staff were far more likely to agree than disagree with the statement (Q69) 'Some people use stress as an excuse for being absent from work'. The lowest scoring statement for both police officers and staff was (Q70) 'Disclosing a mental health problem in the police service is detrimental to future career prospects'. A male constable highlighted the pitfalls,

'Do you want to end up inadvertently having your own personal life exposed and scrutinised. What impact will it have on your job, your future employment. Your state of mind.'

The survey suggests that police officers and staff hold similar attitudes towards people with mental ill health compared to the public. Police data indicates that they are more willing than members of the public to work with someone with mental health issues (see data above). Likewise police respondents are significantly more likely to agree with the statement (Q28) 'Virtually anyone can become mentally ill' than public respondents. This is in contrast to the police specific questions which suggest that officers and staff are reluctant to disclose their mental ill health, and that doing so is detrimental to their career. A perceived lack of trust and confidentiality results in a fear that personal details maybe leaked to colleagues as revealed by a female police staff - 'the stigma that would follow as Im sure attitudes change towards the person confiding .........it is the police service where in my experience nothing it fully confidential'. Of great consequence is that police officers and staff are of the opinion that disclosing a mental health problem in the police service is detrimental to future career prospects. Bullock and Garland (2017) in their research raise similar issues arguing that police culture side-lines those with mental health issues resulting in discrimination which can prevent officers from disclosing or seeking support when it would appropriate to do so.

\section{Conclusion}

Analysis of the data presents police managers and indeed the service with a conundrum. The data suggests that by and large police officers and staff albeit it with some reservations are supportive of people with mental health issues. It appears that they are prepared to work with people with mental ill health yet they are unlikely to seek help from health care professionals or their employer, discuss or share their feelings with family and friends or confide in their colleagues or a current or future employer if they had a mental health problem. This 'won't tell, can't tell culture' must be detrimental to the individual, the organisation and the people they serve.

Forces are rightly attempting to address the issues in a number of ways. However it is clear from the data that much needs to be done in preparing officers, police staff and their managers to deal with the traumatic and stressful issues they deal with. As Dame Carol Black stated in her lecture at the College of Policing 'much of what is provided is window dressing which fails to invest and identify and support police officers and staff with mental health issues much to the detriment of the individual and the organisation' (College of Policing, 2017). The lack of trust amongst colleagues and line managers hinders disclosure and help seeking exacerbating problems further.

The nature of English and Welsh policing is that there are 44 (including BTP) variations in promoting dialogue about mental health. Such a varied approach, where some work better than others, has provided police managers with a comfort blanket of discounting localised research as not generalizable or relevant to their force. However, this research shows there is significant evidence to suggest the majority of police officers and staff across England and Wales believe having a mental health problem and informing their employer is ruinous to their career.

As stated above, many forces are to be commended for introducing mental health awareness training and anti-stigma initiatives. However, it is questionable how many have thoroughly evaluated the impact of the initiatives. Turner \& Jenkins (2018) suggests an education regime based on the findings of attitudinal and cultural surveys which deliver tailored training specific to each force to deliver cultural change. Conducting similar surveys as highlighted here will afford leaders with an opportunity to assess how the culture of their organisation is changing. Indeed the use of the CAMI scale and similar can be used effectivley to measure the impact of pre and post course mental health training.

Courses like Mental Health First Aid Training have be shown to increase participants' knowledge, decrease negative attitudes, and increase supportive behaviours toward individuals with mental health problems (Hadlaczky, et al., 2014). Likewise, peer support networks such as those at Greater Manchester Police and New York Police Department have similar benefits. Peer support can help overcome cultural barriers to help seeking and provide evidence that an organisation values and is empathic to the needs of people with mental ill health. Andersen, et al. (2015) suggest 
utilising peers for post-trauma support as well as facilitating dialogue about the impact of work placed stress.

Stuart (2017) suggests efffective internal antistigma programs delivered to police officers has the potential of improving officers' decision making when encountering people with mental ill health. However, the priority should be informed and able line managers who are trained and confident in supporting officers and staff, where those with 'suspicious minds' are confronted which will prevent officers and staff from concealing their mental ill health.

\section{Acknowledgments}

Police Federation of England and Wales; UNISON (Police \& Justice Service Group), Time to Change \& TNS BMRB.

\section{References}

Abdollahi, M. K. (2002). Understanding Police Stress Research. Journal of Forensic Psychology Practice, 2(2), 1-24. https://doi.org/10.1300/J158v02n02_01

Alderden, M., \& Skogan, W. G. (2014). The place of civilians in policing. Policing: An International Journal of Police Strategies \& Management, 37(2), 259-284. https://doi.org/10.1108/PIJPSM-12-2012-0073

American Psychiatric Association. (2017). What is mental illness?. [Online]

Available at: https://www.psychiatry.org/patients-families/what-is-mental-illness

[Accessed 14 February 2017].

Andersen, J., Papazoglou, K., Koskelainen, M., \& Nyman, M. (2015). Knowledge and Training Regarding the Link Between Trauma and Health: A National Survey of Finnish Police Officers. The Journal of Police Emergency Response, Volume April - June, pp. 1-12. https://doi.org/10.1177/2158244015580380

Bailey, A., Barr, O., \& Bunting, B. (2001). Police attitudes toward people with intellectual disabilty: An evaluation of awareness training. Journal of intellectual disabilty research, 45, 344-350.

BBC. (2016). BBC News. [Online]

Available at: http://www.bbc.co.uk/news/uk-35965223

[Accessed 1st July 2016].

Bell, S., \& Eski, Y. (2016). 'Break a Leg-It's all in the mind': Police Officers' Attitudes towards Colleagues with Mental Health Issues. Policing: A Journal of Policy and Practice, 10(2), 95-101. https://doi.org/10.1093/police/pav041

Bradley, L. (2009). The Bradley Report, London: Department of Health.

Brooker, C., \& Sirdifield, C. (2009). An Evaluation of Mental Health Awareness Training for Probation Staff, Lincoln: University Of Lincoln.

Brown, J. M., \& Campbell, E. A. (1994). Stress and Policing. West Sussex: Wiley.

Bryman, A. (2012). Social Research Methods. 4 ed. Oxford : Oxford University Press.

Bullock, K., \& Garland, J. (2017). Police officers, mental (ill-) health and spoiled identity. Criminology \& Criminal Justice, 1-17. https//doi.org:10.1177/1748895817695856

Burkhill, S. et al. (2016). Using the Web to Collect Data on Sensitive Behaviours: A Study Looking at Mode Effects on the British National Survey of Sexual Attitudes and Lifestyles. PLoS One, 11, 1-12. https://doi.org/10.1371/journal.pone.0147983

Chambers, M. et al. (2010). Nurses' attitudes to mental illness: A comparison of a sample of nurses from 5 europen countries. International Journal of Nursing Studies, 47, 350-362. https://doi.org/10.1016/j.ijnurstu.2009.08.008

Clayfield, J. C., Fletcher, K. E. \& Grudzinskas Jr, A. J. ... (2011). Development and Validation of the Mental Health Attitude Scale for Police Officers. Community Mental Health Journal, 47, 742-751. https://doi.org/10.1007/s10597-011-9384-y

College of Policing. (2017). You Tube GB. [Online]

Available at: https://www.youtube.com/watch?v=rulBWNsgVUk

[Accessed 30 March 2017].

Corrigan, P. (2004). How Stigma interferes with mental health care. American Psychological Association, 59(7), 614-625.

Cotton, D. (2004). The attitudes of Canadian police officers toward the mentaly ill. International Journal of Law and Psychiatry, 27(2), 135-146. https://doi.org/10.1016/j.ijlp.2004.01.004

Couper, M. et al. (2018). New options for national population surveys: The implications of internet and smartphone 
coverage. Social Science Research, 73, 221-235. https://doi.org/10.1016/j.ssresearch.2018.03.008

Creswell, J., \& Plano Clark, V. (2007). Designing and Conducting Mixed Methods Research. Thousand Oaks, CA: Sage Publications.

Crowe, G., \& Stradling, S. G. (1993). Dimensions of perceived stress in a British police force.. Policing Society, 3 , 137-150. https://doi.org/10.1080/10439463.1993.9964663

Cummins, I. (2012). Policing in England and Wales post Bradley. Policing, 27 June, pp. $365-376$. https://doi.org/10.1093/police/pas024

Evans-Lacko, S., Henderson, C., \& Thornicroft, G. (2013). Public knowledge, attitudes and behaviour regarding people with mental illness in England 2009-2012. The British Journal of Psychiatry, 202(s55), pp. 51-57. https://doi.org/10.1192/bjp.bp.112.112979

Evans-Lacko, S. et al. (2010). Development and psychometric properties of the Mental Health Knowledge Schedule. Canadian Journal of Psychiatry, 55, 440-448. https://doi.org/10.1177/070674371005500707

Evans-Lacko, S. et al. (2011). Development and Psychometric Properties of the Reported and Intended Behaviours Scale (RIBS): A stigma related measure. Epidemiology and Psychiatric Sciences, 20, $263-271$. https://doi.org/10.1017/S2045796011000308

Friedrich, B. et al. (2013). Anti-stigma training for medical students: the Education Not Discrimination project. The British Journal of Psychiatry, 202(55), 89-94. https://doi.org/10.1192/bjp.bp.112.114017

Fry, A. J., O'Riordan, D. P., \& Geanellos, R. (2002). Social control agents or front-line carers for people with mental health problems: Police and mental health services in Sydney, Australia.. Health \& Social Care in the Community, 10, 277-286. https://doi.org/10.1046/j.1365-2524.2002.00371.x

Glendinning, A. L., \& O'Keefe, C. (2015). Attitudes towards offenders with mental health problems scale. The Journal of Mental Health Training, Education and Practice, 10(2), 73-84. https://doi.org/10.1108/JMHTEP-08-2014-0023

Godfedson, J. W., Thomas, S. D., Ogloff, J. R., \& Luebbers, S. (2011). Police perceptions of their encounters with individuals experiencing mental illness: A Victorian survey. Australian \& New Zealand Journal of Criminology, 44(2), 180-195. https://doi.org/10.1177/0004865811405138

Hadlaczky, G. et al. (2014). Mental Health First Aid is an effective public health intervention for improving knowledge, attitudes, and behaviour: A meta-analysis. International Review of Psychiatry, 26(4), 467-475. https://doi.org/10.3109/09540261.2014.924910

Hansson, L., \& Markstrom, U. (2014). The effectiveness of an anti-stigma intervention in a basic police officer training programme: a controlled study. BMC Psychiatry, 14(55), 1471-244x. https://doi.org/10.1186/1471-244X-14-55

Heerwegh, D. (2009). Mode Differences Between Face-to-Face and Web Surveys: An Experimental Investigation of Data Quality and Social Desirability Effects. International Journal of Public Opinion Research, 21(1), 111-121. https://doi.org/10.1093/ijpor/edn054

Houdmont, J. (2017). Stressors in police work and thier consequences. In: R. J. Bourke, ed. Stress in Policing: Sources, Consequences and Interventions. Oxon: Routledge, pp. 51-66.

Houdmont, J., \& Elliot-Davies, M. (2016). Police Officer Welfare and Capacity Survey. Nottingham, Nottinham University.

HSE. (2007). Managing sickness absence in the police service, London: HSE.

Kanika, A., Dhillon, M., Juneja, A., \& Sharma, B. (2017). Breaking barriers: An education and contact intervention to reduce mental illness stigma among Indian college students. Psychosocial Intervention, 26, 103 - 109.

Karaffa, K. M., \& Tochkov, K. (2013). Attitudes toward seeking mental health treatment among law enforcement officers. Applied Psychology in Criminal Justice, 9(2), 75-99.

Loftus, B. (2009). Police Culture in a Changing World. Oxford: University Press Scholarship. https://doi.org/10.1093/acprof:oso/9780199560905.001.0001

McCarty, W. P., \& Skogan, W. G. (2012). Job-Related Burnout Among Civilian and Sworn Police Personnel. Police Quarterly, XX(X), pp. 1-19.

Mental Health Foundation. (2016). Fundamental Facts About Mental Health, London: Mental Health Foundation.

MIND. (2015). Blue Light: Research Briefing (no2), London: MIND.

MIND. (2016). Mental health in primary care A briefing for Clinical Commissioning Groups, London: MIND . 
Morgan, M., \& Paterson, C. (2017). 'It's Mental Health, Not Mental Police': A Human Rights Approach to Mental Health Triage and Section 136 of the Mental Health Act 1983. Policing: A Journal of Policy and Practice, Volume 11, pp. 1-11.

Morrison, R. (2011). Nursing students' attitudes toward people with mental illness: do they change after instruction and clinical exposure. The University of South Florida, 77(1), pp. 1-39.

NHS. (2017). SAB NHS Trust. [Online] Available at: http://www.sabp.nhs.uk/advice/mental-illness [Accessed 14 February 2017].

Ombudsman Ontario. (2012). In the Line of Duty, Ontario: Ombudsman Ontario.

Regehr, C. et al. (2013). Predictors of physiological stress and psychological distress in police communicators. Police Practice and Research, 14(6), 451-463. https://doi.org/10.1080/15614263.2012.736718

Sainsbury Centre for Mental Helath. (2009). The Bradley Report and the Governments Response, London: Sainsbury Centre for Mental Health.

Samaritans. (2013). Suicide in the UK, London: Samaritins.

Soomro, S., \& Yanos, P. (2018). Predictors of Mental Health Stigma among Police Officers:. Journal of Police and Criminal Psychology, 1-19. https://doi.org/10.1007/s11896-018-9285-x,

Stuart, H. (2017). Mental Illness Stigma Expressed by Police to Police. Isr Journal Psychiatry Related Science, 54(1), $18-23$.

Taylor, S., \& Dear, M. (1981). Scaling Community Attitudes Toward the Mentally Ill. Schizophrenia Bulletin, 7(2), 225-240. https://doi.org/10.1093/schbul/7.2.225

The Police Federation of England and Wales. (2016). Mental Health must become integral to policing. Police, June/Jily, p. 12.

Thornicroft, G. et al. (2016). Evidence for effective interventions to reduce mental-health-related stigma and discrimination. The Lancet, 387(10023), 1123-1132. https://doi.org/10.1016/S0140-6736(15)00298-6

Time to Change. (2015). Attitudes to Mental Illness 2014 Research Report, London: TNS BMRB.

TNS BMRB. (2015). Attitudes to Mental Illness 2014 Research Report, Prepared for Time to Change, London: TNS BMRB.

Tourangeau, R., Couper, M., \& Steiger, M. (2003). Humanizing self-administered surveys: experiments on social presence in web and IVRsurveys. Computers in Human Behaviours, 19, 1-24. https://doi.org/10.1016/S0747-5632(02)00032-8

Turner, T., \& Jenkins, M. (2018). 'Together in Work, but Alone at Heart': Insider Perspectives on the Mental Health of British Police Officers. Policing: A Journal of Policy and Practice, 12, 1-10.

UNISON. (2014). Police Staff Stress Survey Report, London: UNISON.

Wahl, O. (1999). Mental Health Consumers' Experience of Stigma. Schizophrenia Bulletin, 25(3), 467-478.

Watson, A., Corrigan, P., \& Ottati, V. (2004). Police Officers' Attitudes Toward and Decisions About Persons With Mental Illness. Psychiatric Services, 55(1), 49-53. https://doi.org/10.1176/appi.ps.55.1.49

Westley, W. (1970). Violence and the police : a sociological study of law, custom and morality. Massachusetts: MIT.

WHO. (2001). Mental health: new understanding, new hope., Geneva: World Health Organisation.

Wolff, G., Pathare, S., \& Craig, T. (1996). Community attitudes to menatl illness. British Journal of Psychiatry, 168, 183-190. https://doi.org/10.1192/bjp.168.2.183 
Appendix A

\begin{tabular}{|c|c|c|c|c|c|c|c|c|c|c|}
\hline & & \multicolumn{3}{|c|}{ Public } & \multicolumn{4}{|c|}{ Police officers } & \multicolumn{2}{|c|}{ Police Staff } \\
\hline & CAMI Scale & Agree & Disagree & Mean & Agree & Disagree & Mean & Agree & Disagree & Mean \\
\hline & Fear \& exclusion & $\%$ & $\%$ & & $\%$ & $\%$ & & $\%$ & $\%$ & \\
\hline $\mathrm{q} 47$ & $\begin{array}{l}\text { Locating mental health facilities in a } \\
\text { residential area downgrades the } \\
\text { neighbourhood }\end{array}$ & 14 & 68 & 3.99 & 22 & 49 & 3.49 & 15 & 62 & 3.84 \\
\hline $\mathrm{q} 46$ & $\begin{array}{l}\text { It is frightening to think of people } \\
\text { with mental problems living in } \\
\text { residential neighbourhoods }\end{array}$ & 11 & 74 & 4.12 & 10 & 74 & 4.10 & 8 & 76 & 4.21 \\
\hline $\mathrm{q} 38$ & $\begin{array}{l}\text { I would not want to live next door to } \\
\text { someone who has been mentally ill }\end{array}$ & 9 & 74 & 4.14 & 20 & 47 & 3.50 & 12 & 63 & 3.91 \\
\hline $\mathrm{q} 37$ & $\begin{array}{l}\text { A woman would be foolish to marry } \\
\text { a man who has suffered from mental } \\
\text { illness, even though he seems fully } \\
\text { recovered }\end{array}$ & 9 & 69 & 4.07 & 4 & 82 & 4.38 & 3 & 85 & 4.52 \\
\hline $\mathrm{q} 39$ & $\begin{array}{l}\text { Anyone with a history of mental } \\
\text { problems should be excluded from } \\
\text { taking public office }\end{array}$ & 15 & 64 & 3.87 & 5 & 81 & 4.30 & 3 & 84 & 4.41 \\
\hline $\mathrm{q} 36$ & $\begin{array}{l}\text { People with mental illness should not } \\
\text { be given any responsibility }\end{array}$ & 10 & 72 & 4.05 & 2 & 88 & 4.44 & 1 & 91 & 4.54 \\
\hline $\mathrm{q} 33$ & $\begin{array}{l}\text { People with mental illness are a } \\
\text { burden on society }\end{array}$ & 6 & 84 & 4.44 & 10 & 76 & 4.16 & 7 & 82 & 4.38 \\
\hline $\mathrm{q} 24$ & $\begin{array}{l}\text { As soon as a person shows signs of } \\
\text { mental disturbance, he should be } \\
\text { hospitalized }\end{array}$ & 16 & 67 & 3.90 & 3 & 88 & 4.50 & 3 & 84 & 4.50 \\
\hline & TOTAL & & & 32.57 & & & 32.85 & & & 34.30 \\
\hline & $\begin{array}{l}\text { Understanding and tolerance of } \\
\text { mental illness }\end{array}$ & & & & & & & & & \\
\hline q31R & $\begin{array}{l}\text { We have a responsibility to provide } \\
\text { the best possible care for people with } \\
\text { mental illness ( } \% \text { agree) }\end{array}$ & 93 & 1 & 4.67 & 93 & 2 & 4.65 & 96 & 4 & 4.80 \\
\hline $\mathrm{q} 28 \mathrm{R}$ & $\begin{array}{l}\text { Virtually anyone can become } \\
\text { mentally ill (\% agree) }\end{array}$ & 93 & 2 & 4.65 & 99 & 1 & 4.88 & 99 & 0 & 4.88 \\
\hline $\mathrm{q} 34$ & $\begin{array}{l}\text { Increased spending on mental health } \\
\text { services is a waste of money (\% } \\
\text { disagree) }\end{array}$ & 4 & 88 & 4.52 & 2 & 93 & 4.66 & 2 & 93 & 4.71 \\
\hline $\mathrm{q} 32$ & $\begin{array}{l}\text { People with mental illness don't } \\
\text { deserve our sympathy ( } \% \text { disagree) }\end{array}$ & 5 & 87 & 4.52 & 1 & 93 & 4.66 & 2 & 92 & 4.71 \\
\hline q30R & $\begin{array}{l}\text { We need to adopt a far more tolerant } \\
\text { attitude toward people with mental } \\
\text { illness in our society ( } \% \text { agree) }\end{array}$ & 90 & 2 & 4.55 & 83 & 3 & 4.34 & 90 & 10 & 4.54 \\
\hline q29R & $\begin{array}{l}\text { People with mental illness have for } \\
\text { too long been the subject of ridicule } \\
\text { (\% agree) }\end{array}$ & 77 & 7 & 4.18 & 86 & 3 & 4.36 & 90 & 4 & 4.51 \\
\hline \multirow[t]{3}{*}{ q44R } & $\begin{array}{l}\text { As far as possible, mental health } \\
\text { services should be provided through } \\
\text { community based facilities ( } \% \text { agree) }\end{array}$ & 79 & 5 & 4.20 & 68 & 8 & 3.91 & 69 & 3 & 4.03 \\
\hline & TOTAL & & & 31.28 & & & 31.47 & & & 32.16 \\
\hline & $\begin{array}{llll}\text { Integrating people with mental } \\
\text { community }\end{array}$ & illness & into the & & & & & & & \\
\hline q41R & $\begin{array}{l}\text { People with mental illness are far } \\
\text { less of a danger than most people } \\
\text { suppose }\end{array}$ & 63 & 12 & 3.83 & 58 & 16 & 3.66 & 59 & 14 & 3.77 \\
\hline $\mathrm{q} 26 \mathrm{R}$ & $\begin{array}{l}\text { Less emphasis should be placed on } \\
\text { protecting the public from people }\end{array}$ & 37 & 31 & 3.11 & 16 & 56 & 2.39 & 25 & 40 & 2.76 \\
\hline
\end{tabular}


with mental illness

\begin{tabular}{|c|c|c|c|c|c|c|c|c|c|c|}
\hline $\mathrm{q} 43 \mathrm{R}$ & $\begin{array}{l}\text { The best therapy for many people } \\
\text { with mental illness is to be part of a } \\
\text { normal community }\end{array}$ & 81 & 5 & 4.27 & 66 & 9 & 3.80 & 72 & 8 & 4.00 \\
\hline $\mathrm{q} 45 \mathrm{R}$ & $\begin{array}{l}\text { Residents have nothing to fear from } \\
\text { people coming into their } \\
\text { neighbourhood to obtain mental } \\
\text { health services }\end{array}$ & 70 & 11 & 4.00 & 55 & 19 & 3.57 & 62 & 14 & 3.80 \\
\hline $\mathrm{q} 48 \mathrm{R}$ & $\begin{array}{l}\text { People with mental health problems } \\
\text { should have the same rights to a job } \\
\text { as anyone else }\end{array}$ & 79 & 7 & 4.24 & 83 & 7 & 4.27 & 86 & 5 & 4.47 \\
\hline $\mathrm{q} 42 \mathrm{R}$ & $\begin{array}{l}\text { Most women who were once patients } \\
\text { in a mental hospital can be trusted as } \\
\text { babysitters }\end{array}$ & 31 & 25 & 3.07 & 31 & 16 & 3.22 & 35 & 15 & 3.32 \\
\hline $\mathrm{q} 25 \mathrm{R}$ & $\begin{array}{l}\text { Mental illness is an illness like any } \\
\text { other }\end{array}$ & 78 & 14 & 4.17 & 84 & 12 & 4.33 & 92 & 6 & 4.59 \\
\hline $\mathrm{q} 40 \mathrm{R}$ & $\begin{array}{l}\text { No-one has the right to exclude } \\
\text { people with mental illness from their } \\
\text { neighbourhood }\end{array}$ & 86 & 6 & 4.44 & 84 & 8 & 4.36 & 90 & 5 & 1.01 \\
\hline $\mathrm{q} 27 \mathrm{R}$ & $\begin{array}{l}\text { Mental hospitals are an outdated } \\
\text { means of treating people with mental } \\
\text { illnesses }\end{array}$ & 37 & 27 & 3.15 & 26 & 49 & 2.64 & 31 & 38 & 2.96 \\
\hline & TOTAL & & & 34.28 & & & 32.22 & & & 34.26 \\
\hline
\end{tabular}

Causes of mental illness and the need for special services.

\begin{tabular}{|c|c|c|c|c|c|c|c|c|c|c|}
\hline q35 & $\begin{array}{l}\text { There are sufficient existing services } \\
\text { for people with mental illness }\end{array}$ & 20 & 50 & 3.53 & 6 & 87 & 4.44 & 6 & 83 & 4.38 \\
\hline q22 & $\begin{array}{l}\text { One of the main causes of mental } \\
\text { illness is a lack of self-discipline and } \\
\text { will-power }\end{array}$ & 13 & 69 & 4.05 & 5 & 79 & 4.32 & 7 & 80 & 4.38 \\
\hline \multirow[t]{4}{*}{ q23 } & $\begin{array}{l}\text { There is something about people with } \\
\text { mental illness that makes it easy to } \\
\text { tell them from normal people }\end{array}$ & 16 & 67 & 3.95 & 8 & 77 & 4.25 & 7 & 79 & 4.34 \\
\hline & TOTAL & & & 11.52 & & & 12.99 & & & 13.05 \\
\hline & Total CAMI Score & & & 109.64 & & & 109.51 & & & 113.83 \\
\hline & Mental Health Knowledge Scale & & & & & & & & & \\
\hline q53 & $\begin{array}{l}\text { Most people with mental health } \\
\text { problems go to a health care } \\
\text { professional to get help }\end{array}$ & 46 & 30 & 2.73 & 11 & 73 & 3.87 & 7 & 74 & 3.91 \\
\hline q52R & $\begin{array}{l}\text { People with severe mental health } \\
\text { problems can fully recover }\end{array}$ & 64 & 11 & 3.87 & 59 & 18 & 3.66 & 59 & 21 & 3.70 \\
\hline q67R & $\begin{array}{l}\text { If a friend/colleague (my version) } \\
\text { had a mental health problem, I know } \\
\text { what advice to give them to get } \\
\text { professional help }\end{array}$ & 64 & 19 & 3.70 & 74 & 16 & 3.87 & 72 & 15 & 3.82 \\
\hline q49R & $\begin{array}{l}\text { Most people with mental health } \\
\text { problems want to have paid } \\
\text { employment }\end{array}$ & 73 & 4 & 4.10 & 64 & 6 & 3.93 & 72 & 4 & 4.15 \\
\hline q50R & $\begin{array}{l}\text { Medication can be effective } \\
\text { treatment for people with mental } \\
\text { health problems }\end{array}$ & 78 & 5 & 4.13 & 81 & 4 & 4.13 & 77 & 7 & 4.03 \\
\hline q51R & $\begin{array}{l}\text { Psychotherapy can be an effective } \\
\text { treatment for people with mental } \\
\text { health problems }\end{array}$ & 83 & 2 & 4.32 & 85 & 1 & 4.35 & 90 & 3 & 4.44 \\
\hline & Sub TOTAL & & & 22.85 & & & 23.57 & & & 23.82 \\
\hline
\end{tabular}




\begin{tabular}{|c|c|c|c|c|c|c|c|c|c|c|}
\hline q58R & $\begin{array}{l}\text { To what extent do you agree or } \\
\text { disagree that Drug addiction is a type } \\
\text { of mental illness? }\end{array}$ & 48 & 34 & 3.17 & 33 & 53 & 2.58 & 44 & 34 & 3.06 \\
\hline q59 & $\begin{array}{l}\text { To what extent do you agree or } \\
\text { disagree that Grief is a type of mental } \\
\text { illness? }\end{array}$ & 52 & 31 & 2.73 & 61 & 26 & 2.47 & 58 & 25 & 2.47 \\
\hline q55R & $\begin{array}{l}\text { To what extent do you agree or } \\
\text { disagree that stress is a type of } \\
\text { mental illness? }\end{array}$ & 61 & 25 & 3.54 & 79 & 13 & 4.07 & 80 & 11 & 4.12 \\
\hline q54R & $\begin{array}{l}\text { To what extent do you agree or } \\
\text { disagree that depression is a type of } \\
\text { mental illness? }\end{array}$ & 86 & 6 & 4.37 & 95 & 3 & 4.69 & 95 & 4 & 4.72 \\
\hline q57R & $\begin{array}{l}\text { To what extent do you agree or } \\
\text { disagree that Bipolar Disorder is a } \\
\text { type of mental illness? }\end{array}$ & 87 & 3 & 4.51 & 92 & 3 & 4.65 & 96 & 0 & 4.78 \\
\hline q56R & $\begin{array}{l}\text { To what extent do you agree or } \\
\text { disagree that Schizophrenia is a type } \\
\text { of mental illness? }\end{array}$ & 88 & 1 & 4.60 & 97 & 1 & 4.83 & 98 & 0 & 4.89 \\
\hline & Sub Total & & & 22.92 & & & 23.21 & & & 23.90 \\
\hline & MAKS Total & & & 45.76 & & & 47.08 & & & 48.04 \\
\hline & Reported and intended behaviour & & & & & & & & & \\
\hline q68R & $\begin{array}{l}\text { In the future, I would be willing to } \\
\text { work with someone with a mental } \\
\text { health problem }\end{array}$ & 75 & 6 & 4.16 & 92 & 1 & 4.52 & 93 & 1 & 4.65 \\
\hline
\end{tabular}

\begin{tabular}{lllll}
\hline q20 & What proportion of people do you think might have a mental health problem? & 3 & 2 \\
\hline 1 in 1000 & 6 & 6 & 8 \\
\hline 1 in 100 & 12 & 12 & 12 \\
\hline 1 in 50 & 17 & 31 & 27 \\
\hline 1 in 10 & 29 & 34 & 34 \\
\hline 1 in 4 & 22 & 15 & 17 \\
\hline 1 in 3 & 13 & &
\end{tabular}

\begin{tabular}{|c|c|c|c|c|c|c|c|c|c|c|}
\hline & Consulting GP for help & Likely & Unlikely & & Likely & Unlikely & & Likely & Unlikely & \\
\hline q60R & $\begin{array}{l}\text { If you felt you had a mental health } \\
\text { problem, how likely would you be to } \\
\text { go to your GP for help? }\end{array}$ & 78 & 12 & 4.13 & 76 & 16 & 3.93 & 82 & 11 & 4.13 \\
\hline q61R & $\begin{array}{l}\text { If you felt you had a mental health pro } \\
\text { go to your manager for help? }\end{array}$ & lem, ho & likely wo & you be to & 34 & 54 & 2.65 & 44 & 41 & 3.02 \\
\hline
\end{tabular}

\begin{tabular}{|c|c|c|c|c|c|c|c|c|c|c|}
\hline & $\begin{array}{l}\text { Talking to family and friends and } \\
\text { employers }\end{array}$ & $\mathrm{UC}$ & $\mathrm{C}$ & & $\mathrm{UC}$ & $\mathrm{C}$ & & $\mathrm{UC}$ & $\mathrm{C}$ & \\
\hline q62 & $\begin{array}{l}\text { In general, how comfortable would } \\
\text { you feel talking to a friend or family } \\
\text { member about your mental health, } \\
\text { for example telling them you have a } \\
\text { mental health diagnosis and how it } \\
\text { affects you? }\end{array}$ & 23 & 68 & 5.07 & 46 & 48 & 4.08 & 40 & 56 & 4.41 \\
\hline q64 & $\begin{array}{l}\text { In general, how comfortable would } \\
\text { you feel talking to a current or } \\
\text { prospective employer about your } \\
\text { mental health, for example telling }\end{array}$ & 47 & 34 & 3.65 & 81 & 14 & 2.46 & 80 & 16 & 2.60 \\
\hline
\end{tabular}


them you have a mental health

diagnosis and how it affects you?

\begin{tabular}{|c|c|c|c|c|c|c|c|}
\hline & \multirow[b]{2}{*}{ Police Specific } & \multicolumn{4}{|c|}{ Police officers } & \multicolumn{2}{|c|}{ Police staff } \\
\hline & & Agree & Disagree & Mean & Agree & Disagree & Mean \\
\hline q65R & $\begin{array}{l}\text { If I had a mental health problem I think my managers would support } \\
\text { me. }\end{array}$ & 53 & 28 & 3.31 & 44 & 41 & 3.65 \\
\hline q66R & $\begin{array}{l}\text { If I had a mental health problem I think my work colleagues would } \\
\text { support me. }\end{array}$ & 63 & 19 & 3.56 & 67 & 13 & 3.76 \\
\hline q63 & $\begin{array}{l}\text { If you felt you had a mental health problem, how likely would you } \\
\text { inform your colleagues }\end{array}$ & 27 & 68 & 3.05 & 35 & 60 & 3.42 \\
\hline q70 & $\begin{array}{l}\text { Disclosing a mental health problem in the police service is detrimental to } \\
\text { future career prospects. }\end{array}$ & 75 & 8 & 1.98 & 56 & 19 & 2.48 \\
\hline q71R & $\begin{array}{l}\text { Police Officers/Staff with mental health problems are treated as } \\
\text { sympathetically as officers/staff with physical illness. }\end{array}$ & 20 & 59 & 2.39 & 30 & 43 & 2.79 \\
\hline q69 & Some people use stress as an excuse for being absent from work. & 61 & 18 & 2.42 & 54 & 24 & 2.63 \\
\hline $\mathrm{q} 73 \mathrm{R}$ & $\begin{array}{l}\text { My Force adequately prepares managers to manage officers/staff who } \\
\text { experience mental health issues. }\end{array}$ & 12 & 64 & 2.13 & 21 & 45 & 2.56 \\
\hline $\mathrm{q} 72 \mathrm{R}$ & $\begin{array}{l}\text { My Force adequately prepares officers/staff to deal with the stressful } \\
\text { events they are likely to encounter. }\end{array}$ & 15 & 71 & 2.07 & 25 & 44 & 2.63 \\
\hline q74R & $\begin{array}{l}\text { Debriefing is used effectively to support officers/staff who have } \\
\text { experienced stressful events within my Force. }\end{array}$ & 37 & 46 & 2.76 & 41 & 25 & 3.24 \\
\hline q75R & $\begin{array}{l}\text { Within my Force there is sufficient support for officers/staff experiencing } \\
\text { mental health issues. }\end{array}$ & 27 & 48 & 2.58 & 41 & 31 & 3.06 \\
\hline & Total & & & 26.27 & & & 30.11 \\
\hline
\end{tabular}

* $\mathrm{R}$ indicates reverse score

\section{Copyrights}

Copyright for this article is retained by the author(s), with first publication rights granted to the journal.

This is an open-access article distributed under the terms and conditions of the Creative Commons Attribution License which permits unrestricted use, distribution, and reproduction in any medium, provided the original work is properly cited. 